\title{
Hope for the good 2022 to come
}

\author{
Minh-Hoang Nguyen \\ Ritsumeikan Asia Pacific University \\ Beppu, Oita 874-8577, Japan \\ January 28, 2022
}

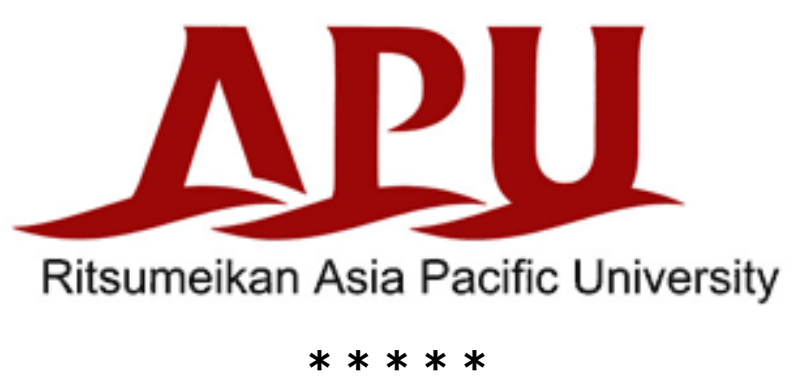

Tết (a.k.a lunar new year) of Vietnamese is coming, and 2021 is near the end. During 2021, I have accomplished various achievements that I could not have imagined before, such as the proposal of the Bayesian Mindsponge Framework [1,2], the first Vietnamese and international books $[3,4]$, the successful combination of Bibliometrics-BayesianMindsponge $[5,6]$, and especially the contribution to the continuing development of the Serendipity-Mindsponge-3D (SM3D) knowledge management framework [7-11].

I thought there would be no good news before the year ends. However, today I received an email stating that I am officially approved to become a doctoral candidacy by the Ritsumeikan Asia Pacific University's Dissertation Committee. Indeed, the approval is very good news and a very meaningful gift for my lunar new year.

I know that luck is not always with me, and opportunity is not always available, so 2022 can be a tough year. However, the candidacy approval and my other achievements in 2021 are strong motivations for me to strive for the best in 2022 .

\section{References}

1. Nguyen MH et al. (2021). Alice in Suicideland: Exploring the suicidal ideation mechanism through the sense of connectedness and help-seeking behaviors. International Journal of Environmental Research and Public Health, 18(7), 3681.

2. Nguyen MH, Le TT, Khuc VQ. (2021). Bayesian Mindsponge Framework. Scholarly Community Encyclopedia. Retrived from: https://encyclopedia.pub/13852 
3. Hoàng VQ, Phương LV, Trung T, Hoàng NM, Toàn HM. (2021). Bản hòa tâu dữ liệu xã hội. Nxb Khoa học Xã hội, Hà Nội.

4. Vuong QH, Nguyen MH, Le TT. (2021). A mindsponge-based investigation into the psycho-religious mechanism behind suicide attacks. Warsaw, Poland: De Gruyter / Sciendo.

5. Nguyen MH, Vuong QH (2021). Evaluation of the Aichi Biodiversity Targets: the international collaboration trilemma in interdisciplinary research. Pacific Conservation Biology. Online Early.

6. Vuong QH, et al. (2021). Assessing the ideological homogeneity in entrepreneurial finance research by highly cited publications. Humanities and Social Sciences Communications, 8, 110.

7. Vuong $\mathrm{QH}$, et al. (2022). Covid-19 vaccines production and societal immunization under the serendipity-mindsponge-3D knowledge management theory and conceptual framework. Humanities and Social Sciences Communications, 9, 22.

8. Vuong QH. (2016). Global mindset as the integration of emerging socio-cultural values through mindsponge processes: A transition economy perspective. In $\mathrm{J}$. Kuada (Ed.), Global Mindsets: Exploration and Perspectives (pp. 123-140). New York: Routledge.

9. Vuong QH, Napier NK. (2015). Acculturation and global mindsponge: An emerging market perspective. International Journal of Intercultural Relations, 49, 354-367.

10. Vuong QH, Napier NK. (2015). Making creativity: the value of multiple filters in the innovation process. International Journal of Transitions and Innovation Systems, 3(4), 294.

11. Napier NK, Vuong QH. (2013). Serendipity as a strategic advantage?. In Wilkinson (ed) Strategic Management in the 21st Century (Vol. 1: The Operational Environment), pp. 175-199. Westport, CT: Praeger/ABC-Clio. 